\title{
複数振動子と支持系の連成振動*
}

\author{
長 嶺 拓 夫*1, 佐 藤 勇一*2, 森 博 輝*1

\section{Coupled Vibration of Oscillators and Their Support}

Takuo NAGAMINE*3, Yuichi SATO and Hiroki MORI

${ }^{* 3}$ Graduate School of Science and Engineering, Saitama University,

255 Shimo-okubo, Sakura-ku, Saitama-shi, Saitama, 338-8570 Japan

\begin{abstract}
In this paper, we describe the coupled vibration of oscillators mounted on a plate hanging on four strings and investigate the features of such vibration. From the experimental and numerical simulation results, the following findings were obtained. First, when the natural frequencies of oscillators and their support are almost the same, the amplitude of the support is very small. This is because the driving forces of oscillators are insufficient. In the case of two oscillators, the phase difference becomes almost $180 \mathrm{deg}$; in the case of three oscillators, it becomes almost $120 \mathrm{deg}$; in the case of four or more oscillators, it becomes variable. Second, when the support vibrates strongly, oscillators synchronize and vibrate with a corresponding phase. Sufficient driving forces of oscillators aree required for the large amplitude of the support:
\end{abstract}

Key Words: Coupled Vibration, Oscillator, Natural Frequency, Phase Locking, Entrainment, Synchronization

\section{1. はじめに}

複数の自厉振動子が互い惊響を与え合う場合，それぞ れの振動子のもつ周期が若干異なっていても, 周期が 一致する同期現象が知られている. 17 世紀の半ばに 細いはりに掛けられた二つの振子時計の周期が一致す る現象として始めて観察された. 以後, 多くの分野に おいて同期現象は観察されている(1).

複数の自厉振動子の連成振動については数多くの研 究がなされている. Blekhman は van der Pol 型の振 動子が一方向に振動する系に取付けられている場合に ついて解析を行い，振動子閒の位相差が 0 または $\pi$ で 同期することを示している( ${ }^{(2)}$. 著者らはメトロノーム を台に載せた系で実験と解析を行い，振動子間の位相 差は台の固有振動数と同期振動数によって影響を受け ることを示している(3). 近藤らは, 同じ系について解 析を行い，概周期振動からカオスが起るルート等を明 らかにしている ${ }^{(4)}$. Bannett らは摩擦の小さい輪上 に載せたはりに, 二つの振動子を載せた系（復元力二 0 の系）で実験と解析を行い，振子と系の重さの比に より現れる振動を示している(5).

これら一連の研究で対象とする振動は, 複数の振子

\footnotetext{
* 原稿受付 2007 年 9 月 19 日.

*1 正員, 埼玉大学大学院理工学研究科(画338-8570さいたま 市桜区下大久保 255).

*2 正員, フェロー, 埼玉大学大学院理工学研究科.

E-mail : nagamine@ mech.saitama-u.ac.jp
}

といった単純な系にも関わらず，多様である. 現状で は, このような比較的単純な系であっても, どの様な 振動が現れるのか十分に明らかになっていない.さら に実際の系では，加振方法や相互作用等が様々である. このようなことから，パラメータによって現れる振動 を検討し現象を理解することは，工学的な問題を考え る上で意味があると考えている.

実際の問題としては, 多数の歩行者の歩行と歩道橋 の横摇れが同期し大きな振動を引き起したことがある. Fujino らは実験的な検討を行い，歩行により橋に横 摇れが生じ，その摇れにより多くの歩行が引き込まれ て同期し，さらに大きな橋の振動を起すことを報告し ている(6). 松久らは身体のリズム生成機構である神経 振動子と歩道橋の横振動の関係を引き込み現象として 検討している(7).

著者らは複数の振動子と支持系が連成振動すること により大きな振動が起ることを防止する目的で研究を 行っている. 本論文では, 糹によって吊られた支持系 に複数の振動子を載せた場合の連成振動について検討 を行った. 全ての振動子がそろって振動し支持系が大 きく振動する場合と振動子が互いの振動を打消し合い 支持系の振動が非常に小さい場合がある. その現れた 振動の特徽について報告を行う。 


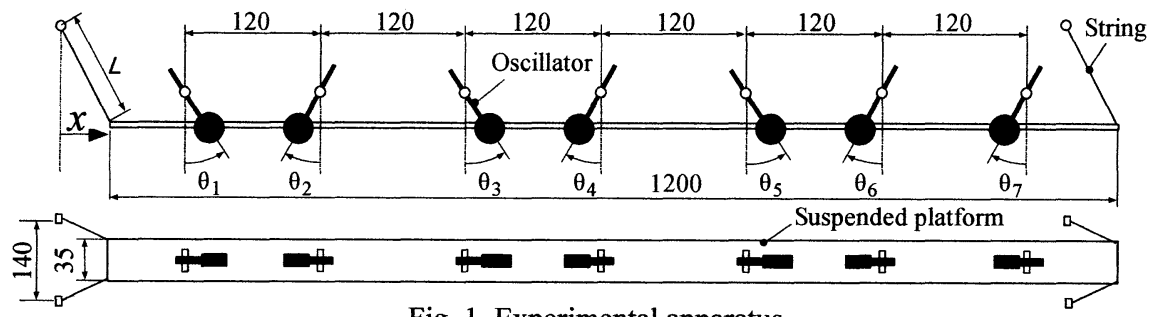

Fig. 1 Experimental apparatus

2. 主な記号

$f_{n}$ : 振動子の振動数 $[\mathrm{Hz}]$

$f_{o}$ : 振動子が微小変位の固有振動数 $[\mathrm{Hz}]$

$f_{p}:$ 支持系の固有振動数 $[\mathrm{Hz}]$

$m:$ 振動子の質量 $[\mathrm{g}]$

$x:$ 台の水平方向変位

$M:$ 台の質量 $[\mathrm{g}]$

$N:$ 振動子の台数

$\gamma$ : 質量比 (振動子の質量 $/$ 総質量 $m /\left(M+\sum m\right)$ )

$\eta$ : 振動子と台の重心から各支点までの長さの比

$\theta_{i}:$ 振動子 $i$ の角变位

$\omega_{i}:$ 振動子の固有角振動数 $[\mathrm{rad} / \mathrm{s}]$

$\omega_{p}:$ 台の固有角振動数 $[\mathrm{rad} / \mathrm{s}]$

$\zeta_{i}: i$ 番目の振動子の減衰比

$\zeta_{p}:$ 台の減衰比

$\Omega_{i}$ : 振動子と台の固有角振動数比 $\left(\omega_{i} / \omega_{p}\right)$

\section{3. 実 験}

$3 \cdot 1$ 実験装置 図 1 は実験装置の概略図である. 4 本の采で吊られた台の上に振動子が載せられている. 系は, 横方向（ $x$ 方向）にのみ台が振動するよう, 上 方に広がるように張ってある. 台の質量は的 $110 \mathrm{~g}$ で ある. 台の固有振動数 $f_{p}$ は系の長さ $L$ にって変える ことができる. 台の固有振動数が振動子の固有振動数 $f_{o}$ を含む $1.8 \sim 4.0 \mathrm{~Hz}$ の範用で実験を行った. 振動子 は太陽電池によって駆動される小型なものを用いてい る. 質量が約 $19 \mathrm{~g}$ で支点から重心までの長さが 16.9 $\mathrm{mm}$ で, 角速度が負 $(d \theta / d t<0)$ で, 角変位が $-14.8<\theta<4.4 \mathrm{deg}$ の範用で駆動トルクが加わる. 振動子の固有振動数 $f_{o}$ は図 2 に示してある. 固有振動 数 $f_{0}$ は $2.66 \sim 2.68 \mathrm{~Hz}$ の範用であり, 振子は, ほぼ同 じ固有振動数であると考えられる.

$3 \cdot 2$ 実験方法 台の系の長さ $L$ により台の固有 振動数を設定する. その後, 初期条件として台を静止 させた状態から，全ての振動子の初期角度を $42 \mathrm{deg}$ にし振動を開始させた. 初期条件としては様々なも

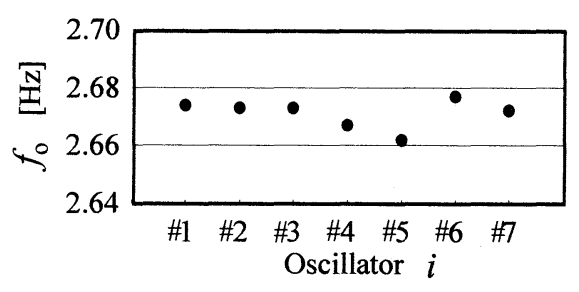

Fig. 2 Natural frequency of oscillators

のがあるが，ここでは、大きな振動が起っているとき の振動子間の位相差が同位相であることから，同位相 が起り易い初期条件として，同位相で実験を開始し検 討を行った. 計測は振動を開始してから 10 分後から 10 分間行った. 計測は非接触変位計と CCD カメラの 画像を用いて行い，振動子と台の変位を計測した. 振 動子は最大で7台用いた。

\section{4. 解 析}

$4 \cdot 1$ 運動方程式 台の振動は小さく, 鉛直方向 の変位成分は十分小さいとして無視している. 振動子 は剛体として扱い，駆動力は一定角変位内で与えられ るものとすると運動方程式は以下のように表わすこと ができる.

台:

$$
\begin{aligned}
& \frac{d^{2} x}{d \tau^{2}}+2 \zeta_{p} \frac{d x}{d \tau}+x \\
& =m \sum_{i=1}^{N}\left\{\left(\frac{d \theta_{i}}{d \tau}\right)^{2}\left(\sin \theta_{i}-x \cos \theta_{i}\right)-\frac{d^{2} \theta_{i}}{d \tau^{2}}\left(\cos \theta_{i}+x \sin \theta_{i}\right)\right\}
\end{aligned}
$$

振動子：

$$
\begin{aligned}
& \frac{d^{2} \theta_{i}}{d \tau^{2}}+2 \zeta_{i} \boldsymbol{\Omega}_{i} \frac{d \theta_{i}}{d \tau}+\mathbf{\Omega}_{i}^{2} \sin \theta_{i} \\
& =-\mathbf{\Omega}_{i}^{2} \frac{d^{2} x}{d \tau^{2}} \cos \theta_{i}-T_{i} \cos \theta_{i}, \quad(i=1 \sim N)
\end{aligned}
$$

ここで, 式 (2) の $T_{i}$ は駆動力であり, 角速度が負 $(d \theta / d t<0)$ でかつ角変位 $-14.8<\theta<4.4 \mathrm{deg}$ の範用 


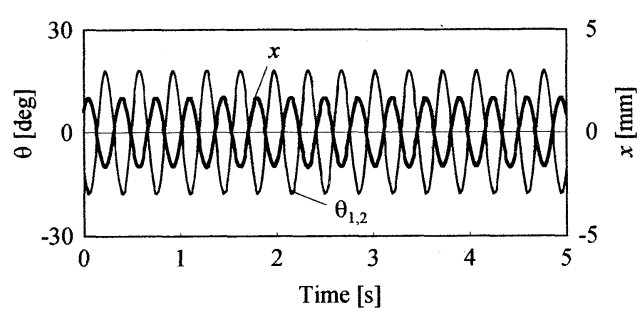

(a) $f_{p}=2 \mathrm{~Hz}$, Type 1

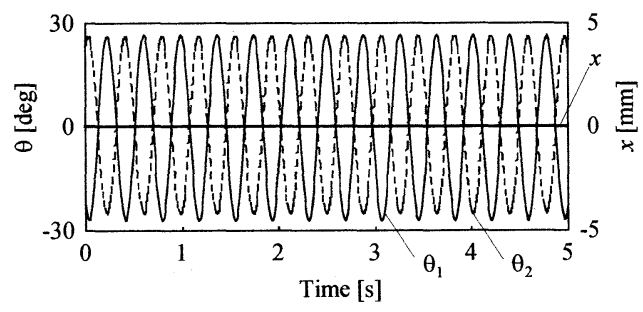

(b) $f_{p}=3 \mathrm{~Hz}$, Type 2

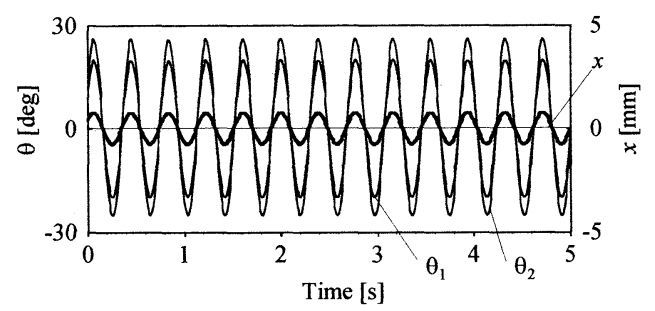

(c) $f_{p}=4 \mathrm{~Hz}$, Type 1

Fig. 3 Experimental results $(N=2)$

で駆動トルクが加わるものとした. 運動方程式 (1) と（2）を数值積分して系の時刻歷応答を調べた. 計 算に使用した各パラメータの值は以下に示寸とおり である. ( $f_{p}=2.8 \mathrm{~Hz}, 7$ 台のとき $)$

$\boldsymbol{\Omega}_{i}=0.95, \gamma=0.040, \quad \eta=0.533, \quad \zeta_{p}=0.0126$, $\zeta_{i}=0.0021 \sim 0.0022, \quad T_{i}=0.008 \sim 0.009$

\section{5. 結果および考察}

$5 \cdot 12$ 台の場合 2台の振動子を台に載せて実 験を行った. 初期条件として, 台を静止させ振動子は 初期角度 $\theta=42 \mathrm{deg}$ （同位相）で振動させた. 図 3 は振動子の角変位 $\theta$ と台の水平方向変位 $x$ を時間に対 して示したものである. 図3(a)は台の固有振動数 $f_{p}$ $=2 \mathrm{~Hz}$ の結果を示したものであり, 振動子の振動数は 台の固有振動数よりも高い. このとき, 初期位相を保

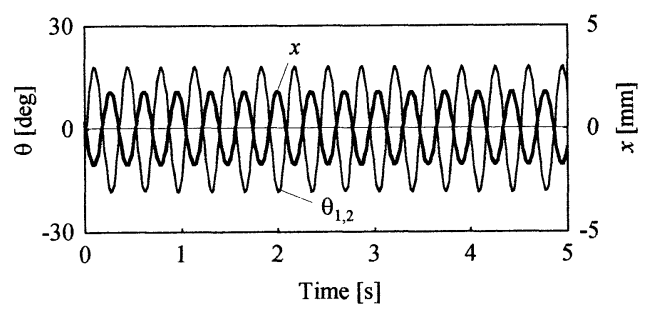

(a) $f_{p}=2 \mathrm{~Hz}$, Type 1

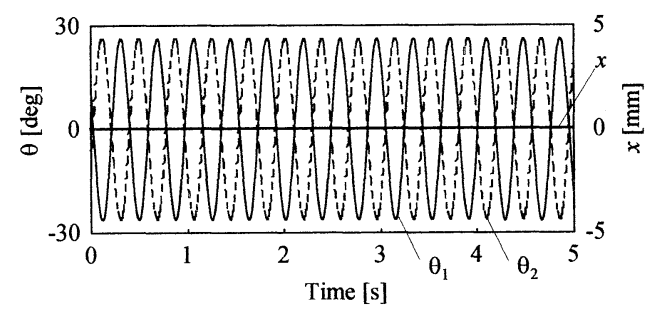

(b) $f_{p}=2.8 \mathrm{~Hz}$, Type 2

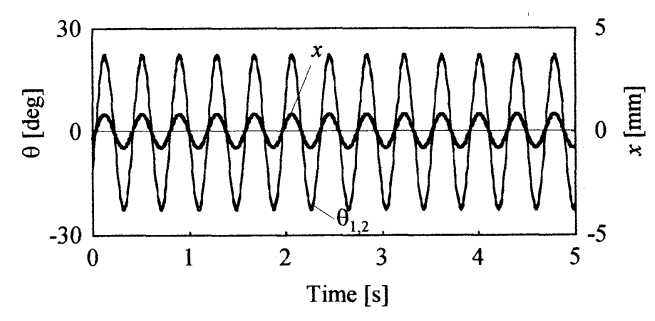

(c) $f_{p}=4 \mathrm{~Hz}$, Type 1

Fig. 4 Calculated results $(N=2)$

持したまま振動が継続し，2台の振動子は 10 分間位相 がずれることなく同位相で振動した.ここでは，この ように振動子同士が同位相で振動する場合を以後タイ プ1と呼ぶことにする. 台と振動子の位相はほぼ逆位 相で振動した.

図 3(b)は台の固有振動数が $3 \mathrm{~Hz}$ の場合である. 振動 子は同じ初期条件の同位相で振動を開始させた. しか し, 間もなく振動は乱れ，その後 2台の振動子は互い に逆位相となって振動した.このように振動子同士の 位相差が約 $180 \operatorname{deg}$ で振動するものを以後タイプ2 呼ぶことにする．また，このとき台の振幅は小さいも のとなった.

図3(c)は台の固有振動数が $4 \mathrm{~Hz}$ の場合であり, 初 期条件は振子同士は同位相である. 振動子の振動数は 台の固有振動数よりも低い：このとき，台と 2 台の振 動子も同位相で振動した. 振動子が同位相で台が大き く振動しているのでこの場合もタイプ1 と以後呼ぶ. 


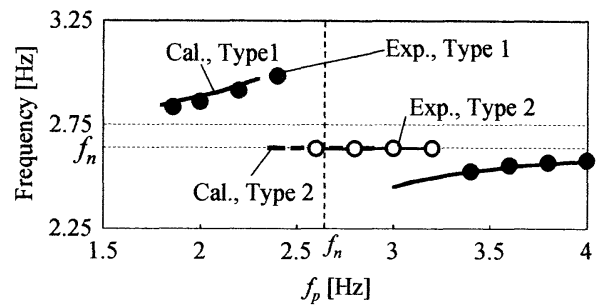

(a)Synchronized frequencies of the system

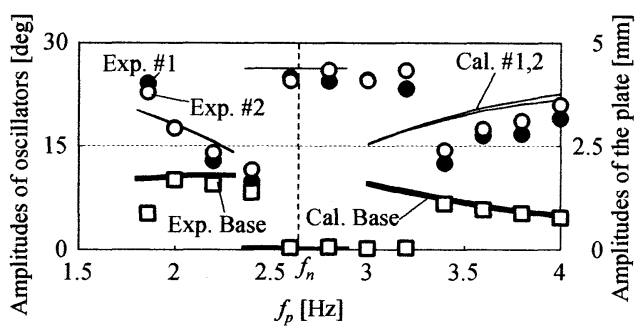

(b) Amplitude of oscillators and the plate
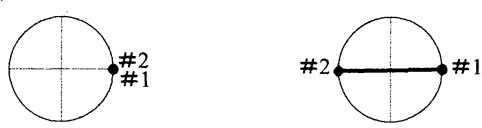

(c) Phase difference

(d) Phase difference

Type $1\left(f_{p}=2 \mathrm{~Hz}\right) \quad$ Type $2\left(f_{p}=2.8 \mathrm{~Hz}\right)$

Fig. 5 Characteristics of coupled vibrations $\left(N=2, f_{n}=2.64 \mathrm{~Hz}\right)$

振動子の振幅は, 図3(b)の場合, 台はほとんど振 動しないため, 静止した台の上での振幅とほぼ同じで ある. しかし，図3(a)，(c)の場合は台が大きく振動 する. その結果, 加振源である振動子の振幅が小さく なっていると考えられる.

図 4 は実験結果と同じ初期条件での数值計算結果を 図 3 と同じように示したものである. 台の固有振動数 は2,28,4 Hzとした. 計算結果と実験結果は定性的に 一致している. 台が大きく振動するタイプ 1 は台の固 有振動数と振動子の振動数が少し離れている $f_{p}=2$, $4 \mathrm{~Hz}$ の場合に起り, 振動子は初期条件の同位相を 保持したままで振動し続ける. 台の振動が小さくなる タイプ 2 は台の固有振動数と振動子の振動数とがほぼ 等しい場合 $\left(f_{p}=2.8 \mathrm{~Hz}\right)$ に起つた. 振動子は初期条件 の同位相を保持せず, 約 $180 \mathrm{deg}$ の逆位相で振動する.

実験結果と数值計算結果の振動数, 振幅を台の固有 振動数に対してまとめたものが図 5である. 図中の点 線 $f_{n}$ は個々の振動子が駆動されているときの振動数
の平均值を参考までに示してある. 初期条件は振動子 の角変位を $42 \mathrm{deg}$ の同位相で振動させている. 振動 は台の固有振動数に対して二つに分かれた. 台の振幅 が大きいタイプ1は，台と振動子の固有振動数が少し 離れている場合に起る. しかし, 振動子と台の固有振 動数がほぼ等しい範用では，台の振幅は小さいタイプ 2が起つた。

初期条件を逆位相として振動させた場合は，実験を 行った $1.8 \sim 4.0 \mathrm{~Hz}$ 全ての範囲でタイプ 2 の振動が 起り, 台が大きく振動するタイプ 1 は起らなかった. このように初期条件の依存性が現れる. 初期条件を逆 位相とした場合，本実験系では全ての範囲でタイプ 2 が起ったが，数值計算を行い質量比 $\gamma$ が小さい場合 などでは，タイプ 2 が起らなくなる振動数範囲が現れ ることを確認している. しかし，ここでは上記の初期 条件（同位相）で現れた振動について特性を検討する.

大きな振動の起るタイプ1の発生範用について, 図 5(b)の振動子の振幅に着目して考える. 実験と計算結 果ともに，振動子と台の固有振動数が近くなるにつれ， 振動子の振幅は小さくなっている. このとき振動子の 振幅が 14〜15 deg 辺りでタイプ 1 が起らなくなりタイ プ 2 の振動が起るようになっている。これは, $-14.8<\theta<4.4 \mathrm{deg}$ が振動子の加振範囲であること によると考えられる. 振動子の振幅が小さくなり，加 振範囲以下になると駆動トルクが減少する. 振動子の 駆動トルクの减少が振動の乱れとなり, 同位相のタイ プ1から，振幅の減少がほとんどないタイプ 2 が起つ たと考えられる.この結果から，タイプ 1 の発生範井 は振動子の加振方法に影響を受けることが考えられる。 (例えば本実験の振動子の加振範囲を $-10<\theta<5 \mathrm{deg}$ として数值計算すると, タイプ 1 の振動子の振幅下限值は約 $10 \mathrm{deg}$ となる．）しか し，ここでは同位相同期で大振動が起る場合，振動子 の振動数と台の固有振動数とが近くなるにつれて振動 子の振幅が小さくなることに着目し，振動子の加振方 法についてはこれ以上検討はしない.

図 5(c)は台の振幅が大きく振動子の位相が同位相 のタイプ 1 を模式的に示し，図 5(d)は台の振幅が小さ く，振動子の位相が約 $180 \mathrm{deg}$ の逆位相で振動する夕 イプ 2 を模式的に示したものである. 振動子\#1を基準 としてタイプ 1 は位相差が約 $0 \mathrm{deg}$, タイプ 2 は位相 差が約 $180 \mathrm{deg}$ であることを表している. また実線で 振動子\#1 と\#2を結んでいるが，これは二つの振動子 の振動数がほぼ同じであることを意味している.この ように振動子間の位相差を表現して考察を行う。 


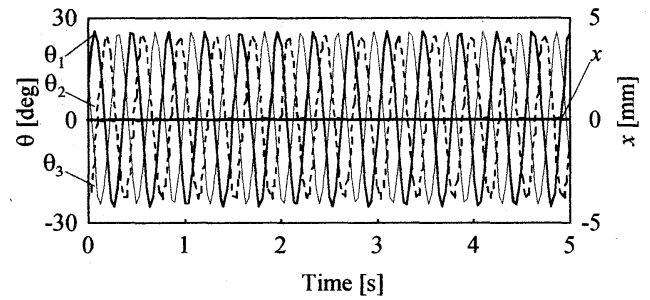

(a) Displacements

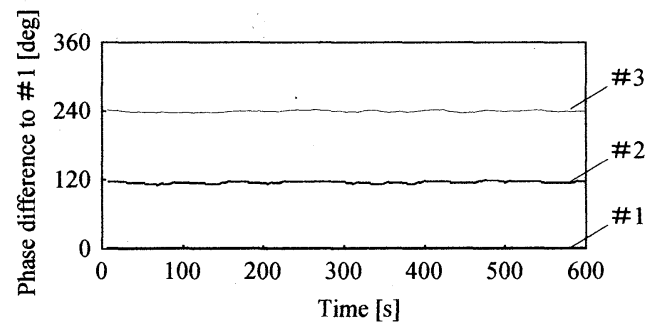

(b) Phase difference

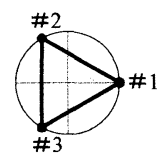

(c) Phase difference, Type 3

Fig. 6 Experimental results $\left(N=3, f_{p}=3 \mathrm{~Hz}\right)$

$5 \cdot 23$ 台の場合 台の固有振動数が振動子の振 動数より少し離れている場合 $\left(f_{p}=2,4 \mathrm{~Hz}\right), 2$ 台 の結果と同じで, 3 台の振動子は初期位相を保持した タイプ 1 で振動した. 図 6，7 は 3 台の振動子を台に 載せた場合で台の固有振動数と振動子の振動数がほぼ 等しいとき（図 $6, f_{p}=3$; 図 7, $f_{p}=2.8 \mathrm{~Hz}$ ) の結果で ある. 変位と位相差を時間に対して示している. ここ で位相差は振動子\#1を基準として0に固定し, 振動子 \#2 と\#3の振動子\#1に対する位相差を示している. 3 台 の振動子は同期振動数 $2.7 \mathrm{~Hz}$ となり, 位相差はそれ ぞれほぼ $120 \mathrm{deg}$ を保持して振動した. 図6(c)はこの ときの位相差を図 5(c) と同じように模式的に示した ものである. ここでは，この位相差の振動をタイプ 3 と呼ぶことにする.

$5 \cdot 34$ 台以上の場合 4 台以上の場合において も初期条件として同位相で振動を開始した場合，台と 振動子の振動数が少し離れているときは, タイプ1の 大きな振動が起った. 図8 8 は, 振動子と台の固有振動 数 (実験結果, $f_{p}=3$; 計算結果, $f_{p}=2.8 \mathrm{~Hz}$ ) が ほぼ等しいときの結果を示したものである. 図8(a), (b)は図 6(b),7(b) と同じように振動子の位相差を時間

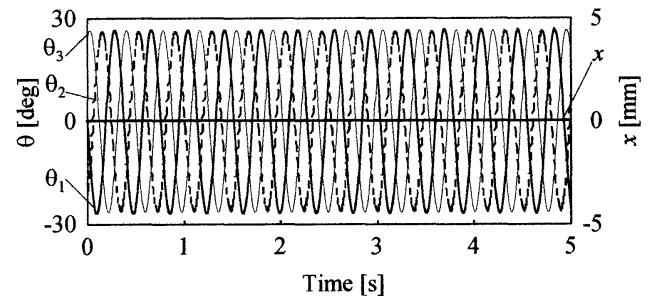

(a) Displacements

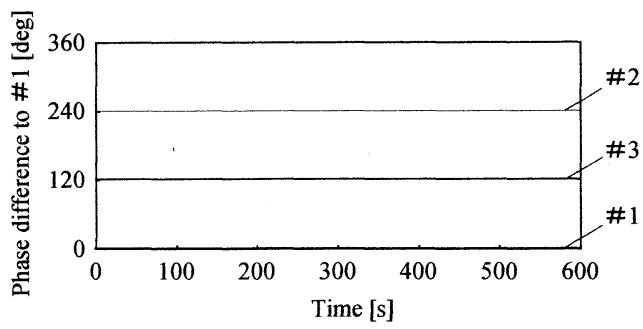

(b) Phase difference

Fig. 7 Calculated results $\left(N=3, f_{p}=2.8 \mathrm{~Hz}\right.$ )

に対して示したものである. 3台までの場合とは異な り，振動子の位相差が一定値に落ち着くことは無かっ た. 図(a-1)は $100 \mathrm{~s}$ のとさ振動子の位相差を図 6(c) のように模式的に表している.この結果より, 全ての 振動子の位相差が一定になっているのではないことが 分る.この結果を用いて，時間に対して同じような位 相変化をする振動子の組を, 線でつないで表した. 線 でつないだ振動子間の振動数の差は $0.002 \mathrm{~Hz}$ 以下の ものであり，ほぼ振動数が一致しているとして表した. 完全な同期ではないが一組として表した振動子同士は, 時間に対して同じように位相を変化させるため, 同期 した組合せとみなして考察を進める.

振動子が 4 台の場合，全ての振動子の位相差が一定 值を保持することはなかった. しかし，詳細にみると 2台が一組になって振動しているようにもみえる. 振 動子の組合せはいつも同じではなく，振動子の組合せ が変わることが実験て観察された.このように4台で の振動は弱い結合関係を保ちながら，相手の振動を打 消し合うように振動していることが分る.

図 8(c), (d)に振動子が5 台の結果を示してある. このときの組合せは 2 台と 3 台の振動子が一組を構成 している. 4 台の場合と同じように振動子の組合せは, いつも同じではなく入れ替わりがあった. 図には示し ていないが，振動子が 6台と7台の場合においても同 じような 2 台と 3 台が一組になって振動する弱い結合 関倸がみられた。 


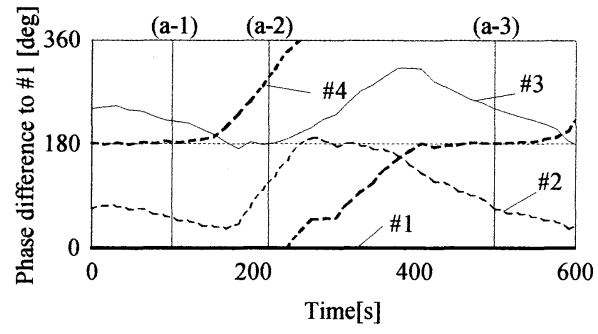

(a) Experimental result, $N=4, f_{p}=3 \mathrm{~Hz}$

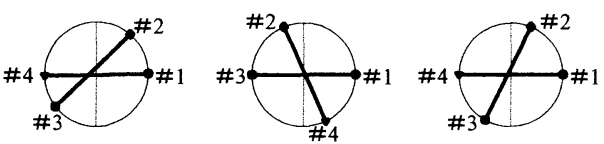

(a-1) $t=100 \mathrm{~s} \quad(\mathrm{a}-2) t=220 \mathrm{~s} \quad$ (a-3) $t=500 \mathrm{~s}$

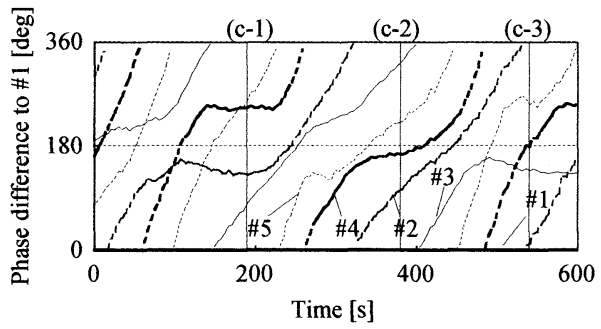

(c) Experimental result, $N=5, f_{p}=3 \mathrm{~Hz}$
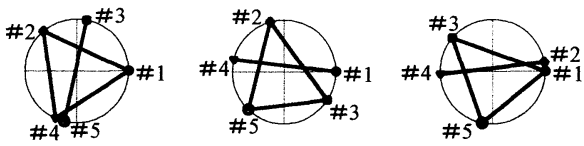

(c-1) $t=190 \mathrm{~s}$

(c-2) $t=380 \mathrm{~s}$

(c-3) $t=540 \mathrm{~s}$

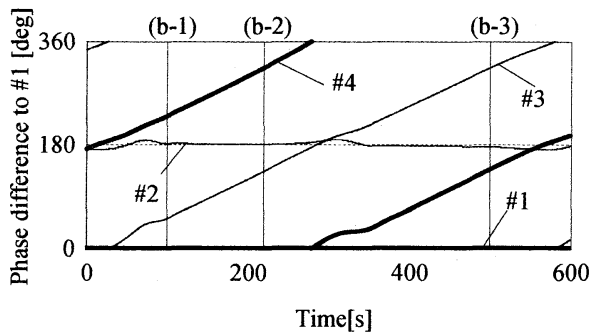

(b) Calculated result, $N=4, f_{p}=2.8 \mathrm{~Hz}$
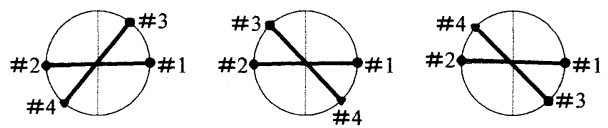

(b-1) $t=100 \mathrm{~s}$

(b-2) $t=220 \mathrm{~s}$

(b-3) $t=500 \mathrm{~s}$

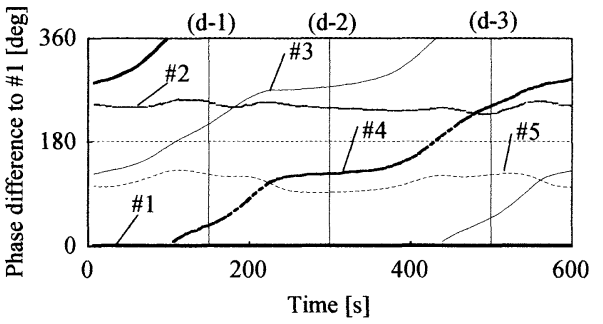

(d) Calculated result, $N=5, f_{p}=2.8 \mathrm{~Hz}$
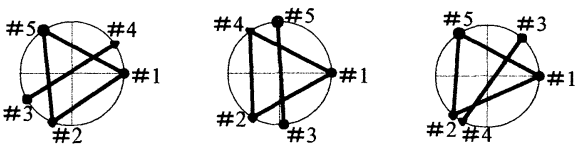

(d-1) $t=150 \mathrm{~s}$

(d-2) $t=300 \mathrm{~s}$

(d-3) $t=500 \mathrm{~s}$

Fig. 8 Phase difference between oscillators

$5 \cdot 4$ 系の振動 図9は采の振動を振動子の台数 $N$ と台の固有振動数 $f_{p}$ に対して示したものである. い ままでと同じように初期条件は振動子に $42 \mathrm{deg}$ の初 期角度を与えて, 同位相で振動を開始させた. 大きな 振動が発生するタイプ 1 は振動子と台の固有振動数が 少し離れている振動数で起っている. しかし, 振動子 と台の固有振動数がほぼ等しい振動数においては, 台 が小さく振動し，お互いの振動を打消すような振動と なる.

この振幅の小さい振動は，2台では位相差が約 180 $\operatorname{deg}$ となるタイプ 2, 3台では位相差が約 $120 \mathrm{deg}$ と なるタイプ 3 となり，振動子の位相は一定值に保持さ れる.4台以上においては位相が一定值に保持される ことはなく，振動子は2台もしくは3台の組合せを作 る. すなわち, タイプ2とタイプ3を重ね合わせた振
動となる. 組合せの振動子は必ずしも固定されておら ず，振動子の組合せは入れ替わりがある.

図 10 は台の最大振幅を振動子の台数 $N$ に対して示 したものである. 全ての振動子が同位相で振動する夕 イプ1のとき, 台数Nが増えるにしたがい，台の振幅 は大きくなることが分る. 振動子と台の固有振動数が ほぼ等しい場合では，台の振幅は小さい。

図 11 は，振動子の台数 $N=5$ の場合で振動子と台 の固有振動数がほぼ等しい場合の実験結果であり, 台 の変位を $10 \mathrm{~s}$ 毎に周波数解析した結果を時間と振動 数比 $f / f_{n}$ に対して示したものである. 振動子は非同 期で振動しているため, 台の振動数比の成分の大きさ は時間に対して変動している. しかし，振幅そのもの は十分に小さい. また，4倍以上の振動数比の成分は ほとんど表れていない. 


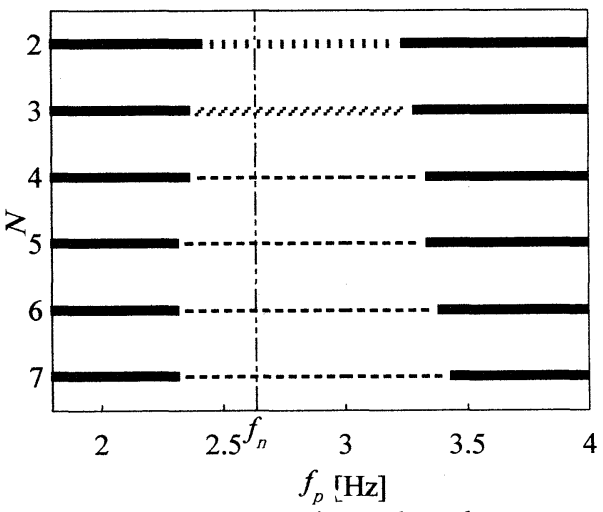

(1) Experimental results

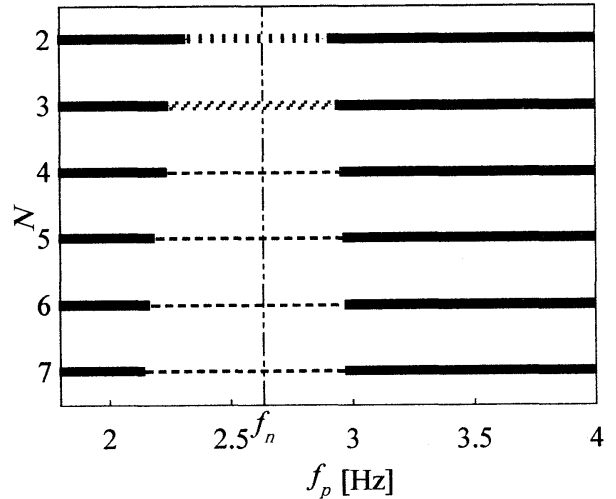

(2) Calculated results

: In-phase synchronization in type 1, $\ldots \ldots \ldots$, :Phase locking in type 2,

\%ore :Phase locking in type 3,

- - - : Non-synchronization in type2 and/or type 3

Fig. 9 Types of vibration

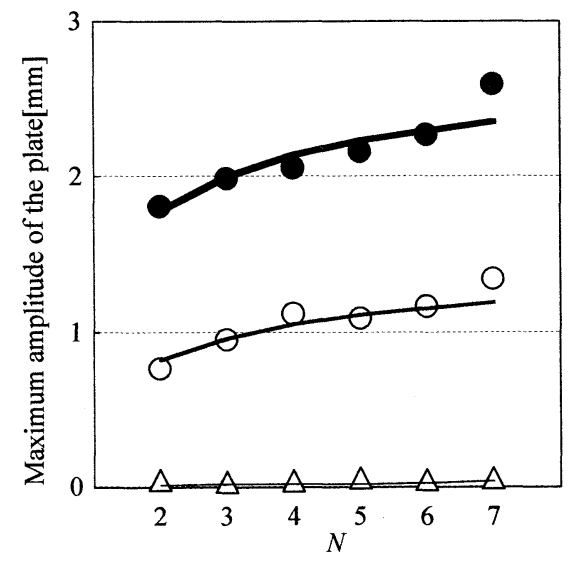

Fig. 10 Maximum amplitudes

(Experimental, $\bigcirc: f_{p}=2.0 \mathrm{~Hz}, \quad \bigcirc: f_{p}=4.0 \mathrm{H}$ $\triangle: f_{p}=3.0 \mathrm{~Hz}$; Calculated, $: f_{p}=2.0 \mathrm{~Hz}$, $\left.-f_{p}=4.0 \mathrm{~Hz}, \longrightarrow: f_{p}=2.8 \mathrm{~Hz}\right)$

次に，振動子と台の固有振動数がほぼ等しい場合， 振動子が互いの振動を打消し合うときの台の変位の周 波数解析を行った. 図 12 はその周波数解析の結果を 示したものである. 2台の場合, 位相差約 $180 \mathrm{deg}$ の 振動となり，振動子 1 台の振動数に等しい成分が主な 振動数比成分となっている. 2 台で振動を打消し合う ため小さな振幅であるが，若干の固体差があるため， 不釣合いを完全に打ち消し合うことができずに，片方 の振動子の影響で, 1 倍の振動数比成分が卓越してい ると考えられる.

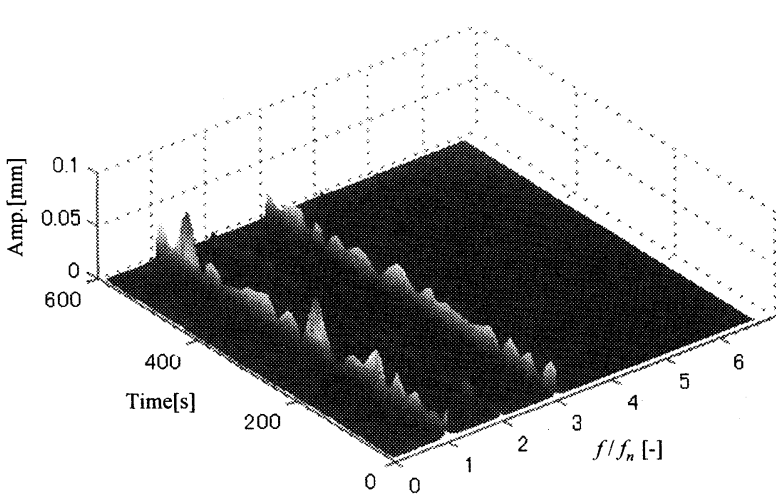

Fig. 11 Observed vibration of the plate $\left(N=5, f_{p}=3.0 \mathrm{~Hz}\right)$

3台の場合，振動子が約 $120 \mathrm{deg}$ の位相差で振動して いる. このため, 振動子の振動数比の 3 倍の成分が卓 越していると考えられる.

4 台以上の場合は 2 倍と 3 倍の振動数比成分が含ま れている.4倍以上の振動数比成分はほとんど現れな い.この振動数比成分からも，2台もしくは3台の振 動子が弱い組合せを作り，互いの振動を打消し合いな がら振動していると考えられる.4台以上では, 打消 し合う振動で同期が起らない理由は以下のように考え られる. 2 台の場合は約 $180 \mathrm{deg}$ の位相差があること により互いの振動を打消し合いながら振動数を平均化 していると考えられ，同様に3台の場合は約 $120 \mathrm{deg}$ の位相差によって互いの振動を打ち消すことが 


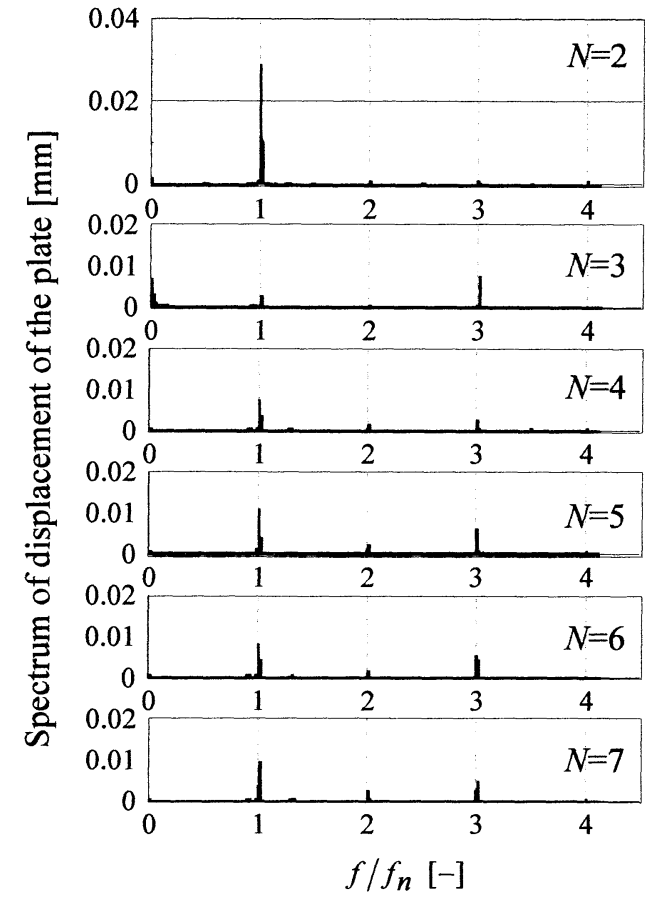

Fig. 12 Frequency-analysis of the observed vibration

(Experimental results, $f_{p}=3.0 \mathrm{~Hz}$ )

できると考えられる. しかし，4台以上の場合は，互 いの振動を打消し合う位相差の組合せが無数にあり, 3台までの場合のように一つの組合せだけではなくな る.このようなことから，4台以上では，位相差が一 定とならないと考えられる.

\section{6. まとめ}

糸で吊られた台の上に，ほぼ特性が同じ振動子を載せ た系で実験と数值計算を行い, 以下の結論が得られた.
振動子が同位相で同期すると支持系は大きく振動し， 振動子の振幅が減少する. 振幅の減少は台の固有振動 数と振動子の振動数が近いほど大きくなる. このよう な同位相同期が起るためには振動子に駆動卜ルクが十 分に入力される必要がある.

一方，同位相同期が起らない場合は，振動子の振幅 の変化はほとんどなく, 支持系は振幅の小さい振動と なる. この振幅の小さい振動では, 振動子が 2 台のと き位相差は約 $180 \mathrm{deg}$ となり，3台のときは約 120 deg となる.4台以上のときは位相差は一定値とはな らず，2台もしくは3台が組となって振動する.

\section{文献}

(1) Pikovsky, A., et al., Synchronization, (2001), pp.1-7, Cambridge University Press.

(2) Blekhman, I. I., Synchronization in Science and Technology, (1988), pp.152-153, ASME Press.

(3) Sato, Y., et al., Synchronized Phenomena of Oscillators, Transactions of the Japan Society of Mechanical Engineers (in Japanese), Series C, Vol.66, No.642(2000), pp.363-369.

(4) Kondou, T., et al., Self-Synchronized Phenomena Generated in Pendulum-Type Oscillators, Transactions of the Japan Society of Mechanical Engineers (in Japanese), Series $C$, Vol.68, No.676 (2002), pp.3499-3506.

(5) Bennett, M., et al., Huygens's clocks, Proceedings of the Royal Society Lond. A, Vol.458(2002), pp.563-579.

(6) Fujino, Y., et al., Synchronization of Human Walking Observed During Lateral Vibration of a Congested Pedestrian Bridge, Earthquake Engineering and Structural dynamics, Vol.22(1993), pp.741-758.

(7) Matsuhisa, k., et al., Synchronization of Walking Rhythm by Lateral Vibration of Footbridge, Preprint of the Japan Society of Mechanical Engineers (in Japanese), D\&D2003 No.03-7(2003), 458, pp.1-6. 